\title{
Federal Structure and Job Satisfaction of Employee: A Case Study of Arghakhanchi District, Nepal
}

\author{
Manoj K. Chaudhary, \\ Ph.D \\ Associate Professor \\ Central Department of Management \\ Tribhuwan University, Nepal
}

\author{
Madhav Adhikari, \\ M.Phil Scholar \\ Faculty of Management \\ Tribhuwan University, Nepal
}

\begin{abstract}
The study proposes a descriptive as well as a causal relationship in order to analyze the interlink between changed federal structure and employee job satisfaction of Arghakhanchi district in Nepal. After this study, it was revealed that the government employees are highly dissatisfied with present organizational structure and want to amend the same. Thus, the paper concluded that the newly amend organizational structure has been expected to be amended for job satisfaction of government level employees for better performance in Nepal. At the most, the results of this study cannot be generalized for the large population. So, further study can be done by taking more sample size for the research and applying probability sampling methods.
\end{abstract}

\section{Key Words}

Federal Structure, Job Satisfaction, Employee, Amend, Arghakhanchi, Nepal.

\section{Introduction}

An employee's attitude towards his/her job explains the individuals' job satisfaction. Different aspects of a job such as supervision, salary, incentives, work environment, team, promotion, job stability, career growth etc serves the function of this satisfaction. This shows the level of motivation and satisfaction of an employee. An organization finds a satisfied employee as an important asset as he/she tries to perform to the best of his/her capabilities. An employee's emotions towards his/her workplace and job are revealed by the observation of this satisfaction. It helps to figure out the level in which the job is satisfying the individual's needs Likewise, a study as such is used to measure an employee's intentions towards their workplace (Javed, Balouch, \& Hassan, 2014). The general definition of job satisfaction includes the degree to which a worker value their work. Many attempts to define job satisfaction have been ruled by the person-environment fit ideal. In a simple term, the higher an individual's work atmosphere meets his or her wants, values, or personal attributes, better the intensity of job satisfaction. Regardless of theoretical approaches, many researchers have found out at least two common types of preceding 
variables annexed with job satisfaction. They are environmental factors and personal characteristics. Environmental preceding refers to causes linked with the job itself or work atmosphere, while personal causes highlight the employer's nature and habits (Ellickson, 2002).

In 2015, Nepal declared a new constitution that anticipates local legislation, and three layers of governments - federal, province and local. The federal democratic republic system was institutionalized by this constitution as it put an end to elongated changeover. Thus, jurisdiction was given to the people. The modified parliamentary mechanism offered more elaborate constitutional commissions. This also included a vision of economic and social upheaval, balance and economic progress. The Commission for Local Level Restructuring classified 753 regional government entities throughout the nation, which included 293 urban and 460 rural municipalities. The aim of reformed regional legislation are many. This includes regulating an orderly and fully functional government at the bottom level. Likewise, it also involves providing public assistance to the grassroots in an elaborate way. It also involves the implementation of activities associated with social and economic development that helps to raise the lifestyles of the locals. Finally, it aims to develop a regionally accepted administration (Acharya, 2018).

The rising regional legislation dominance on service arrangement is followed in bits to lessen the difference among the people and the state forces, as regional authorities are thought to be annexed to the constituents. Nearby governments can prompt more noteworthy interest of residents in discussions with government offices to address deficiencies in help arrangement, which could upgrade public assistance conveyance. Additionally, if nearby chosen authorities and administrative authorities are ordered with more noteworthy obligations, residents are required to check out decisions and apply expanding pressure for more responsible help conveyance and take part in elections as well (Adhikari and Hachhethu, 2017).

Civil service is the public authority's way to address the public vision, mission, objectives, points and destinations. It assumes a conspicuous part in guaranteeing great administration in changed settings. Hence, it should be very much persuaded, devoted, submitted and skillful. In like manner, it should be forward looking, dynamic and ready to work with the connected organs of the public authority in order to achieve the political mission of the nation as per the arising desire and yearnings of the individuals (Basnyat, 2008).

\section{Literature Review}

Satisfaction in job is normally connected with inspiration however these are two unique parts of it. For example, it very well may be either quantitative or subjective when related with an individual sensation of accomplishment, (Mullins, 2005). This incorporates any blend of mental, physiological and natural conditions that cause an individual to honestly say that they are happy with their positions (Hoppock, 1935). Vroom characterizes work fulfillment as the individual's feelings towards their job designations (Vroom, 1964).

Good and ideal mentalities towards the work shows job fulfillment, while adverse and troublesome perspectives towards it show disappointment, as the term alludes to individuals' sentiments towards it (Armstrong, 2006). Satisfaction in Job is a specialist's pride and accomplishment at work and is seen to be straightforwardly connected to profitability and the representative's very own prosperity. It additionally infers that the worker makes the most of his/her work, does it well, and is remunerated for it. It likewise suggests eagerness and happiness at work, Job fulfillment is vital to acknowledgment, pay, advancement, and the accomplishment of different objectives that lead to satisfaction (Kaliski, 2007). 
Job satisfaction epitomizes representatives' emotions and convictions about their work. It can go from extraordinary fulfillment to outrageous disappointment. Furthermore, individuals likewise can have perspectives about different viewpoints like nature of work, associates, pay, and so on (George and Jones, 2008).

Employee satisfaction is the person's enthusiastic reaction to his/her position, which brings about the benefit that the worker makes. Non-attendance and change, firmly connected with work fulfillment, straightforwardly impact the organization's fruitful turn of events and proficiency (Warr and Inceoglu, 2012). Hence, it should be estimated with cautious perception of their conclusions, sentiments and encounters (Barling, Kelloway, and Iversion, 2003).

Employee Engagement gives a quantifiable degree to measure a worker's positive or negative passionate connection to their work, associates and association, which impacts their eagerness to learn and perform at work (Shanmuga and Vijayadurai, 2014).

Job satisfaction impacts the person as well as institutional, cultural, and public variables. Components like compensation, advantages and advancements, working condition, administration and social relationship, varieties of errands included, and openings and difficulties are critical to work fulfillment (Al-Hussami, Saleh, Abdalkader, and Mahadeen, 2011). Fulfilled representatives are known to be more imaginative and inventive professionally (Bakotic, 2016).

Discoveries from an investigation of nursing personnel in Nepal show that some of them were happy with their chances and standards utilized for advancement, possibility rewards, working conditions, installment and incidental advantages. The numerous principles and techniques in the working conditions diminished work effectiveness, and new ideas for workforce advancement were not all around advanced. In spite of the fact that work wages was positioned low as a work fulfillment area, numerous non-money related variables assumed key parts. Numerous factors had solid connection with job satisfaction, in a multivariate examination the commitment from each was more modest. Singular factors may appear to show but yet not decide it (Sapkota, et al., 2019).

Government rivals the private area for the best ability, and administrative pioneers should attempt to meet or surpass worker commitment levels in the private area. The best private area associations endeavor to expand representative commitment for better execution and results, and government pioneers need to stick to this same pattern (Partnership for Public Service, 2020).

Efficiency and nature of work are significant as well. Occupation satisfaction essentially improves the nature of work, and positive feelings energize innovative reasoning. Uncertain individuals may face unnecessary challenges (Brief and Weiss, 2002). Contacts, gatherings and associations with collaborators or bosses likewise impact work fulfillment (Rogelberg, Allen, Shanok, Scott, and Shuffler, 2010). An examination in Poland with 215 respondents shows that the work air mostly affected job fulfillment while the way of life of the organization had the least. Among singular variables and factors, business security was evaluated as the most significant. However, as classes, the most significant components were related with relational relations and financial parts of work. In this way, as indicated by the respondents, work soundness greatly affects work fulfillment (Sypniewska, 2013).

Organization advancement approaches and strategies likewise assume a major part. A few organizations lean toward interior advancement, while some enroll new representatives. Remunerating best workers with advancements is the sign of fruitful organizations. This urges the representative to amplify his/her endeavors. Their high confidence drives them to perform certainly and effectively, expanding efficiency. Favorable and dynamic workers demonstrate their 
qualification for advancement by improving their abilities through instruction, preparing and improvement programs(Gupta, 2011).

The manner by which representatives inside an organization communicate is its authoritative culture, which makes it one of a kind. It can contrarily affect worker inspiration and execution. Positive culture builds representatives' responsibility. An effective culture urges workers to play out their undertakings with energy and eagerness, and builds work fulfillment, responsibility, and resulting endeavors exhausted by representatives. Representatives assume liability for the association's prosperity when they accept they are essential to the organization development (Yildirim, Acaray, and Candan, 2016).

\section{Materials and Methods:}

In this research descriptive as well as causal relationships were analyzed using quantitative data analysis to establish relationships of independent variables with dependent variables. Job satisfaction is a dependent variable whereas remuneration, job security, job rotation, wage policy, and training etc are independent variables.

In this study, population means all the government offices in Nepal's Arghakhanchi district. Forty-Five government offices were studied. Stratified random
Sampling was used to select respondents from all three tiers of government. Administrative, education, health and development offices in provincial and central level of government offices were covered. Lower level, middle level and toplevel employees were subjected to questionnaire surveys.

Primary data were collected by conducting a questionnaire survey of all sectors. Three hundred and fifteen respondents were subjected to a questionnaire survey to subjectively explain data related to job satisfaction in government offices.

Primary data was analyzed systematically in Excel and SPSS software. Statistical tools such as Mean, Correlation analysis and .... were calculated to establish relationships among variables. Likert scale has been used to find the results. A five point scale ranging from one to five was adopted and transformed to relative importance indices (RII) for each factor.

\section{Results and Analysis}

Various factors are present that affect job satisfaction of employees. Table 1 shows parameters affecting job satisfaction of Local Employees. The Relative Importance Index has been taken as a key indicator for calculation of job affecting factors. 
Table 1 Factors Affecting Job Satisfaction of Overall Employees

\begin{tabular}{|c|c|c|c|c|c|c|c|c|}
\hline \multirow[t]{2}{*}{$\begin{array}{l}\text { Factors Affecting Job } \\
\text { Satisfaction }\end{array}$} & \multicolumn{2}{|c|}{ Federal } & \multicolumn{2}{|c|}{ Provincial } & \multicolumn{2}{|c|}{ Local } & \multicolumn{2}{|c|}{ Overall } \\
\hline & $\begin{array}{r}\text { RI } \\
\text { I }\end{array}$ & $\begin{array}{l}\mathrm{Ra} \\
\mathrm{n} \\
\mathrm{K}\end{array}$ & $\begin{array}{r}\text { RI } \\
\text { I }\end{array}$ & $\begin{array}{r}\operatorname{Ran} \\
\mathrm{k}\end{array}$ & $\begin{array}{r}\text { RI } \\
\text { I }\end{array}$ & $\begin{array}{l}\mathrm{Ra} \\
\mathrm{n} \\
\mathrm{k}\end{array}$ & RII & $\begin{array}{r}\operatorname{Ran} \\
\mathrm{k}\end{array}$ \\
\hline $\begin{array}{l}\text { Promotion/Career } \\
\text { Development }\end{array}$ & 0.945 & 1 & $\begin{array}{r}0.9 \\
3\end{array}$ & 1 & $\begin{array}{r}0.92 \\
8\end{array}$ & 1 & 0.934 & 1 \\
\hline Working environment & 0.931 & 2 & $\begin{array}{r}0.9 \\
2\end{array}$ & 3 & $\begin{array}{r}0.92 \\
6\end{array}$ & 2 & 0.926 & 2 \\
\hline Job Training & 0.925 & 3 & $\begin{array}{r}0.9 \\
3 \\
\end{array}$ & 2 & $\begin{array}{r}0.91 \\
3 \\
\end{array}$ & 6 & 0.922 & 3 \\
\hline $\begin{array}{l}\text { Communication with Senior } \\
\text { Management }\end{array}$ & 0.916 & 4 & $\begin{array}{r}0.9 \\
2\end{array}$ & 3 & $\begin{array}{r}0.92 \\
3\end{array}$ & 3 & 0.919 & 4 \\
\hline $\begin{array}{l}\text { Work Performance } \\
\text { Evaluation } \\
\text { System }\end{array}$ & 0.911 & 5 & 0.9 & 6 & $\begin{array}{r}0.91 \\
3\end{array}$ & 6 & 0.909 & 5 \\
\hline Team Sprit & 0.907 & 6 & $\begin{array}{r}0.8 \\
8 \\
\end{array}$ & 10 & $\begin{array}{r}0.92 \\
1 \\
\end{array}$ & 4 & 0.906 & 6 \\
\hline Job Security & 0.904 & 7 & 0.9 & 7 & $\begin{array}{r}0.91 \\
3\end{array}$ & 6 & 0.905 & 7 \\
\hline Remuneration /Salary & 0.869 & 9 & 0.9 & 7 & $\begin{array}{r}0.91 \\
5\end{array}$ & 5 & 0.890 & 8 \\
\hline
\end{tabular}

\begin{tabular}{|l|r|r|r|r|r|r|r|r|} 
& & & 0.9 & & 0.88 & & & \\
Work Life Balance & 0.878 & 8 & 1 & 5 & 7 & 10 & 0.883 & 9 \\
\hline Job rotation/relocation & 0.869 & 9 & 9 & 9 & 2 & 9 & 0.880 & 10 \\
\hline Stress Management & 0.864 & 12 & 7 & 11 & 4 & 11 & 0.866 & 11 \\
\hline Reward /Punishment & & & 0.8 & & 0.85 & & & \\
Approach & & & & & & & & \\
\hline & 0.869 & 9 & 7 & 12 & 4 & 12 & 0.864 & 12 \\
Organizational Structure & 0.778 & 13 & 2 & 13 & 3 & 13 & 0.802 & 13 \\
\hline
\end{tabular}

Table 1 shows that Promotion and career development is the main affecting factor getting position 1 with RII value 0.933 . Other important affecting factors are Working
Environment (RII=0.926), Job Training (RII=0.922) Communicating with Senior Management (RII=0.919), work performance evaluation system (RII=0.909). Team spirit, 
Job Security, Remuneration Salary, reward/punishment approach, stress management and organizational structure are least prioritized by government employees.

\section{Employee Adjustment Act and Government Employees}

Government Employees have expressed version on employee adjustment process which was held on 2018/19 A.D. Table 4-13 shows the data related to it.

Table 2 Government Employees' Version on Employee Adjustment Act and Wage Policy

\begin{tabular}{|l|r|r|r|}
\hline & $\mathrm{N}$ & \multicolumn{1}{c|}{ Mean } & \multicolumn{1}{c|}{ Std. Deviation } \\
\hline Employee Adjustment Process & 315 & 2.2975 & 1.0056 \\
\hline $\begin{array}{l}\text { Amendment in inter province and } \\
\text { inter local level transfer }\end{array}$ & 315 & 4.5670 & .78008 \\
\hline Present Salary Increment System & 315 & 2.1830 & 1.04894 \\
\hline $\begin{array}{l}\text { Newly Formed Organizational } \\
\text { Structure } \\
\text { Provision of Promotion and Career } \\
\text { Development in Act }\end{array}$ & 315 & 2.9306 & .90194 \\
\cline { 2 - 4 } & 315 & 3.0826 & 2.81692 \\
\hline
\end{tabular}

\begin{tabular}{|l|r|r|r|} 
Amendment in Promotion and Job & 315 & 4.1702 & .68314 \\
\hline $\begin{array}{l}\text { Rotation Approach } \\
\text { Organizational Structure and } \\
\text { Remuneration-Wage Policy }\end{array}$ & 315 & 4.2818 & .61730 \\
\hline
\end{tabular}

(Field Survey)

Table 2 reveals that local employees are not satisfied with the employee adjustment process, with mean value only 2.29. From the mean value it has been seen that amendment in present organizational structure and wage policy (4.28), amendment in promotion and job rotation approach (4.17) and amendment in inter province and inter local level transfer (4.53) is highly prioritized by government employees. Present Salary Increment System, with mean value
2.18 , shows that government employees are very dissatisfied with the mechanism. This might be because of minimum salary increment in two years in contrast to skyrocketing market price and price inflation. After the initiation of federal structure, provincial and local level employees are bound to stay within their province or local government. The mean value for amendment for inter province and inter local level transfer (4.53) shows that employees are very 
eager to amend the law to enable inter province and inter local level transfer. Newly formed organizational structure has a mean value 2.93, showing that employees are not satisfied with

it. The mean value for amendment in present organizational structure and remuneration-

wage policy (4.28) shows that government employees are highly dissatisfied with present organizational structure and want to amend it, and bring remuneration and wage policy in line with present market price. Amendment in promotion and job rotation approach, with mean value 4.17, shows that government employees are very dissatisfied with present job rotation and promotion mechanism. It shows that government must amend the Federal Act to motivate employees, the real pillars of the new federal structure of Nepal.

\section{Findings and Conclusion}

In Nepal' changed federal structure, job satisfaction of government employees is pivotal because they play a crucial role in people's daily lives. Research as conducted in Arghakhanchi district to find job satisfaction of government employees in the changed political scenario. Their response to lack of job rotation system in local and provincial level and their recommendation for inter province and inter local level transfer (Mean=4.56) shows the need to amend the transfer mechanism in the federal system. The present system of leave, job position and job authority seem satisfactory. Tork performance evaluation system and decisionmaking process do not seem satisfactory. The result shows that these parameters need to be improved to enhance performance of government employees.

Major factors affecting job satisfaction seem to be promotion and career development $(\mathrm{RII}=0.934)$ followed by working environment ( $\mathrm{RII}=0.926$ ), Job training ( $\mathrm{RII}=0.922)$, Communication with senior management $(\mathrm{RII}=0.919)$ and proper work performance evaluation system $(\mathrm{RII}=0.909)$. It shows that an appropriate promotion mechanism with proper working environment, training, and evaluation can enhance performance of government employees. The results showed that remuneration, job security, work life balance, organizational structure, job rotation, rewardpunishment approach, stress management, communication with management can play a moderate role in the improvement of their performance.

Employee adjustment process (2.29) seems dissatisfactory from the eye of government employees. As per KII it was forcefully done irrespective of feelings of employees. Employees are also dissatisfied with the present job rotation system and expect amendment in law enabling inter province and inter local government level transfer. Present salary increment mechanism (2.18) is also not satisfactory as it does not keep up with inflation. From the result it is seen that newly formed organizational structure and wage policy is expected to be amended for better performance of government level employees.

\section{REFERENCES}

[1]. Acharya, K. K. (2018). Local Governance Restructuring in Nepal: From Government to Governmentality. Dhaulagiri Journal of Society and Anthropology,

[2]. Adhikari, B., \& Hachhethu, D. (2017). Diagnostic Study of Local Governance in Federal Nepal. Kathmandu: The Asia Foundation.

[3]. Al-Hussami, M., Saleh, M., Abdalkader, R., \& Mahadeen, A. (2011). Predictors of Nursing Faculty Members Organizational Commitment in Government Universities. Journal of Nursing.

[4]. Armstrong, M. (2006). A Handbook of Human Resource Management Practice. London: Kogan Page Publishing.

[5]. Barling, J., Kelloway, E., \& Iversion, R. (2003). Journal of Applied Psychology.

[6]. Basnyat, C. (2008). Civil Service in Context of New Nepal. Issues on Public Service Commission. 
[7]. Boone, H. N., \& Boone, D. A. (2012). Analyzing Likert Data. Journal of Extension.

[8]. Brief, A., \& Weiss, H. (2002). Organizational Behavior: Affect in the Work Place. Annual Review of Psychology, 279-307.

[9]. Cortina, J. M. (1993). what is cofficient alpha? An Examination of Theory and Applications. Journal of Applied Psychology, 98-104.

[10]. Ellickson, M. C. (2002). Determinants of Job Satisfaction of Municipal Government Employees. Public Personnel Management.

[11]. George, J., \& Jones, G. (2008). Understanding and Managing Organizational Behavior. New Jersey: Pearson/Prentice Hall.

[12]. Government of Nepal. (2015). Constitution of Nepal . Kathmandu: Ministry of Law, Justice and Parliamentary Affairs.

[13]. Government of Nepal. (2017). Employee Readjustment Act. Kathmandu: Ministry of Federal Affairs and Administration.

[14]. Hee, O. C., Yan, L. H., Rizal, A. M., Kowang, T. O., \& Fei, G. C. (2018). Factors Affecting Employee Job Satisfaction: A Conceptual Analysis. International Journal of Academic Research in Business and Social Sciences.

[15]. Hoppock, R. (1935). Job Satisfaction. New York: Harper and Brothers.

[16]. Isen, A. (2005). Positive Effect and Decision Making. Psychology of Emotions, 527-549.

[17]. Javed, M., Balouch, R., \& Hassan, F. (2014). Determinants of Job Satisfaction and Its Impact on Employee Performance and Turnover Intentions. International Journal of Learning and Development.

[18]. Masood, A., Ain, Q. U., Aslam, R., \& Rizwan, M. (2014). Factors Affecting Employee Satisfaction of the Public and Private Sector Organizations in Pakistan. International Journal of Human Resources Studies.

[19]. Mullins, J. (2005). Management and Organizational Behavior. Essex: Pearson Education Limited.

[20]. Partnership for Public Service. (2020). Retrieved January 05, 2020, from https://bestplacestowork.org/analysis/

[21]. Paudel, B. (2020). Satisfaction, Study on Job Satisfaction of Civil Engineers in Gandaki
Provincial Government. Kathmandu: Tribhuwan University.

[22]. Rogelberg, S., Allen, J., Shanok, L., Scott, C., \& Shuffler, M. (2010). Employee Satisfaction with Meetings: A Contemporary Facet of Job Satisfaction. Human Resource Management, 149-172.

[23]. Sageer, A., Rafat, D., \& Agarwal, P. (2012). Identification of Variables Affecting Employee Satisfaction and Their Impact on the Organization. IOSR Journal of Business and Management, 32-39.

[24]. Sapkota, A., Poudel, U., Pokhrel , J., Ghimire, P., Pradhan, A., Bhattarai, G., et al. (2019). Factors Associated with Job Satisfaction among Graduate Nursing Faculties in Nepal.

[25]. Schimst, S. W. (2007). The Relationship between Satisfaction with Workplace Training and Overall Job Satisfaction. Human Resource Development, 493-495.

[26]. Shakya, U. R. (2009). Ethics in Nepalese Civil Services Sector:How does it matter? Administration and Management Review, 1-2.

[27]. Shanmuga, P., \& Vijayadurai, J. (2014). Employee Engagement in Organizations. Europian Journal of Business and Management.

[28]. Singh, A. S., \& Masuku, M. B. (2014). Sampling Techniques and Determination of Sample Size in Applied Statistics Research: An Overview. International Journal of Economics, Commerce and Management .

[29]. Somiah, M. K. (2015). http://shodhganga.inflibnet.ac.in/bitstream/106 03/2589/12/12_chapter\%203.pdf.

[30]. Spector, P. E. (2012). Industrial and Organizational Psychology: research and practice. Wiley.

[31]. Sypniewska, B. A. (2013). Evaluation of Factors Influencing Job Satisfaction. Contemporary Economics.

[32]. Vroom, V. (1964). Work and Motivation. New York: John Wiley and Sons.

[33]. Warr, P., \& Inceoglu, I. (2012). Job Engagement, Job Satisfaction and Contrasting Associations with Person Job Fit. Journal of Occupational Health Psychology, 129-138. 